\title{
Enrichment of sliced apple fruit with Bacillus coagulans
}

\author{
Mayra Cristina Soto-Caballero', Carlos Horacio Acosta-Muñiz², Viridiana Chávez-Leal', \\ Gustavo González-Aguilar ${ }^{3}$, Cintya Geovanna Soria-Hernández ${ }^{4}$, Graciela Dolores Avila-Quezada ${ }^{1 *}$ \\ ${ }^{1}$ Universidad Autónoma de Chihuahua, Facultad de Ciencias Agrotecnologicas. Escorza 900, col. Centro. Chihuahua, Chihuahua, 31500 , \\ Mexico, ${ }^{2}$ Centro de Investigación en Alimentación y Desarrollo A.C. Coordinación Cuauhtémoc. Av. Río Conchos s/n Parque Industrial. \\ Cuauhtémoc, Chihuahua. 31570, Mexico, ${ }^{3}$ Centro de Investigación en Alimentación y Desarrollo A.C. Carretera a la Victoria Km. 0.6, \\ Hermosillo, Sonora, 83000 Mexico, ${ }^{4}$ Instituto Tecnologico de Monterrey, School of Engineering and Science. Av. Eugenio Garza Sada 2501 \\ Sur, Monterrey, Nuevo León, 64849 Mexico.cintya.soria@tec.mx
}

\section{A B S T R A C T}

\begin{abstract}
The effect of addition of the probiotic agent Bacillus coagulans to apples by applying a vacuum impregnation process was studied. Apple slices were impregnated with a sucrose isotonic solution (IS) of $14^{\circ} \mathrm{Bx}$ containing $10^{10} \mathrm{CFU} \mathrm{g} \mathrm{g}^{-1}$ of $B$. coagulans. The effect of vacuum $(22,29,36$ and $43 \mathrm{~cm} \mathrm{Hg}$ for $5 \mathrm{~min}$.) and relaxation time (35, 60, 120, 180 and $204 \mathrm{~min}$.$) was studied. The highest impregnation of IS$ (up to $17 \%$ ) in apple slices was obtained in long relaxation times $(120,180$ and $204 \mathrm{~min}$.) and low vacuum pressures (22 cm $\mathrm{Hg}$ ). The highest vacuum pressure $(43 \mathrm{~cm} \mathrm{Hg})$ at any relaxation time yielded high concentration of impregnated $B$. coagulans cells $\left(4 \times 10^{7}\right.$ UFC $\mathrm{g}^{-1}$ ) into apple slices. The results confirm that $B$. coagulans at this concentration is satisfactory and similar to that concentration levels of probiotics contained in products existing in the market. Therefore, this article proposes the application of probiotic microorganisms in apple, being this fruit a suitable food matrix for probiotic bacteria.
\end{abstract}

Keywords: Apple; Enriched fruits; Probiotics; Vacuum impregnation

\section{INTRODUCTION}

Due to latent risk of consuming contaminated food (AvilaQuezada et al., 2010), the addition of probiotics to food products has proven to be an effective therapy to reduce gastrointestinal pathogens (Elshaghabee et al., 2017).

Probiotics benefit the composition of the intestinal microbiota and human health, therefore their consumption has increased (Granato et al., 2010). Fruits generally provide good carrier matrices for probiotic microorganisms. Besides, the growing number of vegetarian individuals reinforces the importance of the development of probiotic products such as fruits and vegetables (Peres et al., 2012; Ranadheera et al., 2010). Furthermore, these foods contain nutrients easily assimilated by probiotics (Kourkoutas et al., 2006; Peres et al., 2012)

Bacillus coagulans is a spore-forming bacterium that has been successfully used to enrich food because it is an excelent probiotic agent (Abhari et al., 2016; Haldar and Gandhi, 2016; Jager et al., 2016). It produces bacteriocin toxins, which exhibit a wide spectrum of antibiotic activity (Cotter et al., 2013; Ugras et al., 2013; Sumi et al., 2014).

The addition of probiotics to minimally processed food through vacuum impregnation is a highly efficient technique to enrich fruit (Flores-Andrade et al., 2017). Vacuum impregnation is a technology applicable to functional foods, in which pressure gradients are used to incorporate a functional component into a food matrix without modifying its sensory properties (Fito et al., 1996), where a significant amount of isotonic solution is incorporated to the tissue (Diamante et al., 2014) with a high concentration of probiotic cells (Andrade et al., 2017; Betoret et al., 2012; Comandini et al., 2010).

Recently, vacuum impregnation in vegetable foods has been studied with special attention to food fortification and enrichment (Joshi et al., 2016; Tappi et al., 2017; Zunin et al., 2017).

This article proposes the application of probiotic microorganisms in apple, being this fruit a suitable food

\footnotetext{
*Corresponding author:

Graciela Dolores Avila-Quezada, Universidad Autónoma de Chihuahua, Facultad de Ciencias Agrotecnologicas. Escorza 900, col. Centro.

Chihuahua, Chihuahua, 31500, Mexico. Phone: +52 (614) 4391844. E-mail: gdavila@uach.mx gavilaq@gmail.com
} 
matrix for probiotic bacteria. Therefore, the objective of this study was to evaluate feasibility to riches apple slices with $B$. coagulans through different conditions of vacuum impregnation.

\section{MATERIALS AND METHODS}

\section{Raw material and preparation}

Apple (Malus domestica Borkh.) fruits cv. Golden delicious were purchased in a local market. Fifty apples of adequate ripening were selected (14\% of soluble solids content) (Guan et al., 2015), using a hand-held refractometer (Master Series, 0 - 30\%, Atago). Fruit were conditionated at room temperature and the washed and cut into slices $(\sim 8 \mathrm{~mm}$ thickness) along the horizontal axis.

\section{Sucrose isotonic solution (IS) and culture preparation} Fruit impregnation techniques use IS with high concentrations of probiotic bacteria for short periods of time (Russo et al., 2014) by vacuum impregnation (Alzamora et al., 2005). For this, an IS was prepared with distilled water and 14\% sucrose (Sigma, USA), according to soluble solids content of the apple. Osmotic pressure for application of IS was $9.83 \mathrm{~atm}$. The solution was thermally sterilized at $121^{\circ} \mathrm{C}$ during $20 \mathrm{~min}$. Osmotic pressure was also calculated.

B. coagulans was obtained from the Culture collection of CIAD (Centro de Investigación en Alimentación y Desarrollo) in Cuauhtemoc, Chihuahua, Mexico. Since the bacterium requires a rich mixture of organic substrates to grow in vitro (Jurenka, 2012), we tested several enriched media. The best culture to grown the bacterium was trypticase soy broth (TSB) (BD Bioxon). After shaking for $48 \mathrm{~h}$ at $37^{\circ} \mathrm{C}$, the culture was centrifuged and resuspended in distilled water to obtain a high concentration of $2 \times 10^{10}$ CFU $\mathrm{mL}^{-1}$, as suggested by Russo et al. (2014).

\section{Vacuum impregnation experiment}

Vacuum impregnation was carried out using a vacuum system comprised a glass vacuum desiccator (Wheaton Dry-Seal, capacity $5 \mathrm{~L}$ ) and a vacuum pump (Felisa pump, Mod. 1600 L, Mexico) (Alzamora et al., 2005). Four unpeeled apple slices $(\sim 50 \mathrm{~g})$ were immersed in $100 \mathrm{~mL}$ IS in beakers containing $2 \times 10^{10} \mathrm{CFU} \mathrm{mL} \mathrm{mL}^{-1}$, and then placed in a vacuum desiccator. Vacuum impregnation pressures of 22, 29, 36 and $43 \mathrm{~cm} \mathrm{Hg}$ were applied during $5 \mathrm{~min}$. These intervals are within those recommended by other authors (Mujica-Paz, et al., 2003; Neri et al., 2016; Russo et al., 2014; Schulze et al., 2012). After the vacuum period, atmospheric pressure was restored, and the samples were kept in the solution for five relaxation times (35- 204 min.). The vacuum impregnation process is represented in the
Fig. 1. Slices were drained for $1 \mathrm{~min}$. to remove excess of probiotic solution. Sample weight was recorded before and after treatment to calculate initial and final bacterial concentration impregnated per $g$ of fruit.

Variables and conditions were established according to previous studies of vacuum impregnation of apples, which indicate high levels of impregnation (Mujica-Paz, et al., 2003; Neri et al., 2016; Schulze et al., 2012). Since the effect of vacuum pressure on the added Bacillus is not known, we wanted to test low vacuum levels, extending the immersion time after vacuum application (relaxation time).

\section{Probiotic bacterial count}

One g of each impregnated apple was aseptically homogenized in $9 \mathrm{~mL}$ of sterile buffered peptone water, using a stomacher blender (IUL Instruments). Serial dilutions of each sample were spread on trypticase soy agar plates and incubated at $37^{\circ} \mathrm{C}$ for $48 \mathrm{~h}$, under anaerobic conditions, using the AnaeroGenTM atmospheric generator system (Oxoid Ltd, United Kingdom). After this time, bacteria were counted.

All plate counts inoculated from each treatment and replication of Bacillus-impregnated apples were converted to $\mathrm{CFU} \mathrm{g}{ }^{-1}$, and the average colony counts of five replicates plated in duplicate were transformed to base-10 logarithms.

For the enumeration of B. coagulans, the method of the United States Food and Drug Administration, the International Organization for Standardization (1993) and the Official Methods of Analysis (2000) of the AOAC were used.

\section{Impregnated apple morphology}

The morphology of the impregnated apple with B. coagulans was observed by Scanning Electron Microscopy (SEM, Evo MA 25, Carl Zeiss, Oberkochen, Germany). The sample was frozen at $-80^{\circ} \mathrm{C}$ and then lyophilized (Virtis FM 25 EL 85, Gardiner, NY, USA). Subsequently, cross-sections of the lyophilized apple were made, placed on carbon tape, coated with gold and observed by SEM using an accelerating voltage of $8.0 \mathrm{kV}$ and a working distance of $8.0 \mathrm{~mm}$.

\section{Experimental design and statistical analysis}

Variables of the vacuum impregnation process were vacuum pressure $(22-43 \mathrm{~cm} \mathrm{Hg})$ and relaxation time (35204 min.) were subjected to an experimental design and optimization by central-composite design. The propose of this methodology (linear and quadratic regretion and ANOVA) is to optimize the variable of interest by determining the optimal conditions of the factors in the 
system. Experimental design and statistical analysis were carried out in Minitab 16 software (Statistical Software, USA).

\section{RESULTS AND DISCUSSION}

A significant effect of $(p<0.05)$ for volume fraction impregnated $(\mathrm{X})$ and $B$. coagulans concentration were vacuum pressure, relaxation time and vacuum pressurerelaxation time interaction. The quadratic terms of vacuum pressure and relaxation time were significant $(p<0.05)$ only for the probiotic concentration. Determination coefficient values $\left(\mathrm{R}^{2} \mathrm{adj}\right)$ were $>82 \%$, indicating that the statistical model applied provides an adequate description of the experimental data (Table 1).

\section{Volumetric impregnation parameter (X)}

The X parameter estimated IS impregnated into the pores of the fruit during vacuum impregnation process. The -isoterm refers to the same solute concentration in the apple tissue and in the solution in which it was immersed. Fig. 2 shows the effect of IS conditions on impregnated volume fraction. The $\mathrm{X}$ values varied from 3 to $17 \%$, while pressure of 36 and $43 \mathrm{~cm} \mathrm{Hg}$ led to an X value of 12 - 17\% in all relaxation times tested. Higher incorporation of IS into the apple was obtained at $43 \mathrm{~cm} \mathrm{Hg}$ and relaxation times of 35 and 60 min., thus, high vacuum pressure and short relaxation times, results in fast and high impregnation of IS into apple slices. The pressure of $43 \mathrm{~cm} \mathrm{Hg}$ is within the range used by various authors for impregnation of probiotics in apple cv. Golden delicious and other cultivars

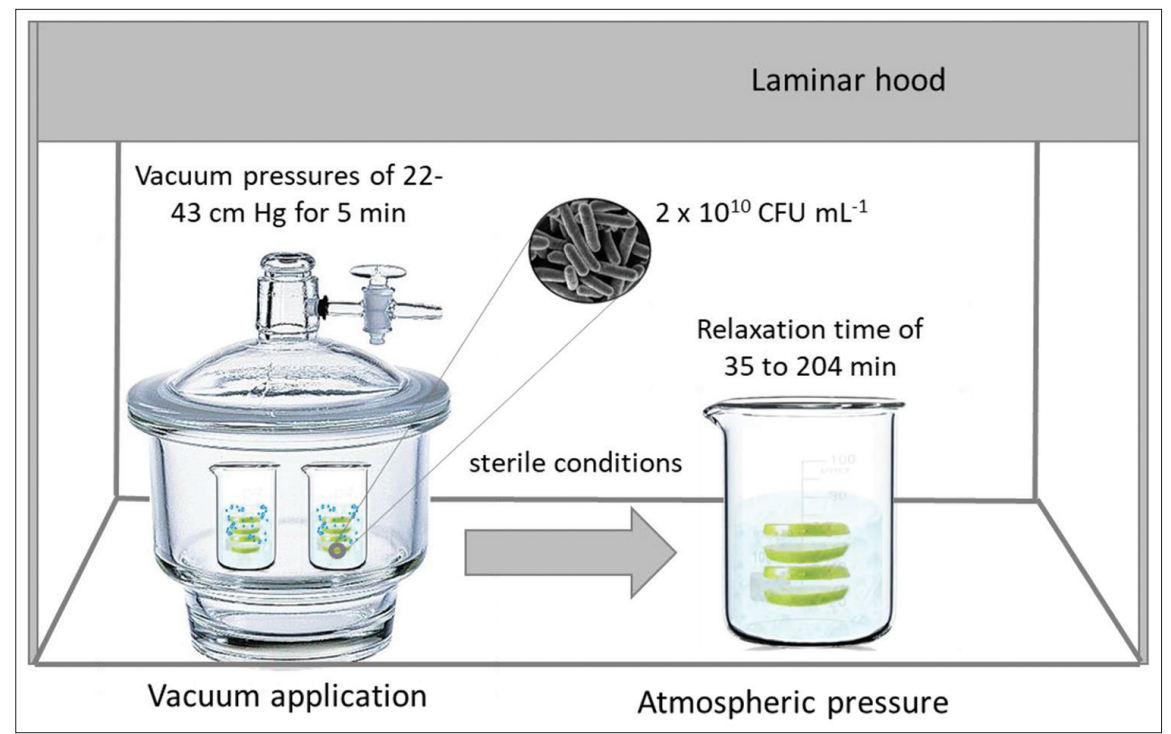

Fig 1. Vacuum impregnation experiment

Table 1: Analysis of variance (ANOVA) of level impregnation and concentration of B. coagulans in apple as a function the different factors evaluated

\begin{tabular}{|c|c|c|c|c|c|}
\hline Source & Df & SS & $\mathbf{F}$ & $p$ & $\mathbf{R}^{2} \mathrm{ad}$ \\
\hline \multicolumn{6}{|l|}{ Volumetric impregnation parameter (X) } \\
\hline Vacuum pressure & 1 & 0.002 & 27.10 & 0.001 & 82.3 \\
\hline Relaxation time & 1 & 0.001 & 14.84 & 0.006 & \\
\hline Vacuum pressure - vacuum pressure & 1 & 0.000 & 0.59 & 0.467 & \\
\hline Relaxation time - relaxation time & 1 & 0.000 & 3.12 & 0.121 & \\
\hline Vacuum pressure - relaxation time & 1 & 0.001 & 14.85 & 0.006 & \\
\hline Pure error & 4 & 0.000 & & & \\
\hline Total & 12 & 0.007 & & & \\
\hline \multicolumn{6}{|l|}{ Impregnated B. coagulans concentration } \\
\hline Vacuum pressure & 1 & $1.1 \times 10^{14}$ & 48.88 & 0.000 & 91.7 \\
\hline Relaxation time & 1 & $5.5 \times 10^{13}$ & 23.04 & 0.002 & \\
\hline Vacuum pressure - vacuum pressure & 1 & $1.2 \times 10^{13}$ & 9.68 & 0.017 & \\
\hline Relaxation time - relaxation time & 1 & $1.0 \times 10^{14}$ & 42.24 & 0.000 & \\
\hline Vacuum pressure - relaxation time & 1 & $4.2 \times 10^{13}$ & 17.42 & 0.004 & \\
\hline Pure error & 4 & $8.0 \times 10^{11}$ & & & \\
\hline Total & 12 & $3.4 \times 10^{14}$ & & & \\
\hline
\end{tabular}

Df-degrees of freedom; SS-sum of squares; $F$ and $p$-values of $F$ and $p$, respectively $(p<0.05)$. 
(Mujica-Paz et al., 2003; Neri et al., 2016; Schulze et al., 2012) who found high impregnation percentages.

These results are similar to those reported by Puente et al. (2009) for apple cv. Granny Smith impregnated with lactic acid bacteria, who achieved an $\mathrm{X}$ parameter of $10 \%$ using vacuum impregnation. Assis et al. (2019) also used vacuum impregnation of calcium lactate, and report an X value between $9 \%$ and $15 \%$ of the initial volume of apple cv. Fuji samples. Betoret et al. (2003) found a higher X value of around $20 \%$ in apple cv. Granny Smith.

Treatments at all relaxation times presented similar $\mathrm{X}$ values between 12 and $14 \%$ at $36 \mathrm{~cm} \mathrm{Hg}$. These results show that it could be possible to incorporate $12-14 \mathrm{~mL}$ of IS with B. coagulans into the structure of $100 \mathrm{~g}$ of fresh apple slices by vacuum impregnation at $36 \mathrm{~cm} \mathrm{Hg}$.

\section{Vacuum impregnation of $\boldsymbol{B}$. coagulans}

The addition of probiotics into value-added products, such as ready-to-eat apple slices, is a good functional food alternative. Apple pores are elongated (Mendoza et al., 2010), their size varies among apple cultivars and the ripening stage of the fruit. Apple pore diameter has been reported to be $\sim 12 \mu \mathrm{m}$ and linear weighted average diameter is $\sim 100 \mu \mathrm{m}$ (Castagnini et al., 2015). Due to the pore size, this matrix can host different bioactive compounds including probiotics.

B. coagulans have an average size of $0.9 \times 3.0$ to $5.0 \mu \mathrm{m}$, therefore, it can be easily incorporated into apple pore slices, furthermore, in the intercellular spaces of apple tissues ranging from $172-2297 \mu \mathrm{m}$ (Lewicki and PorzeckaPawlak, 2005).

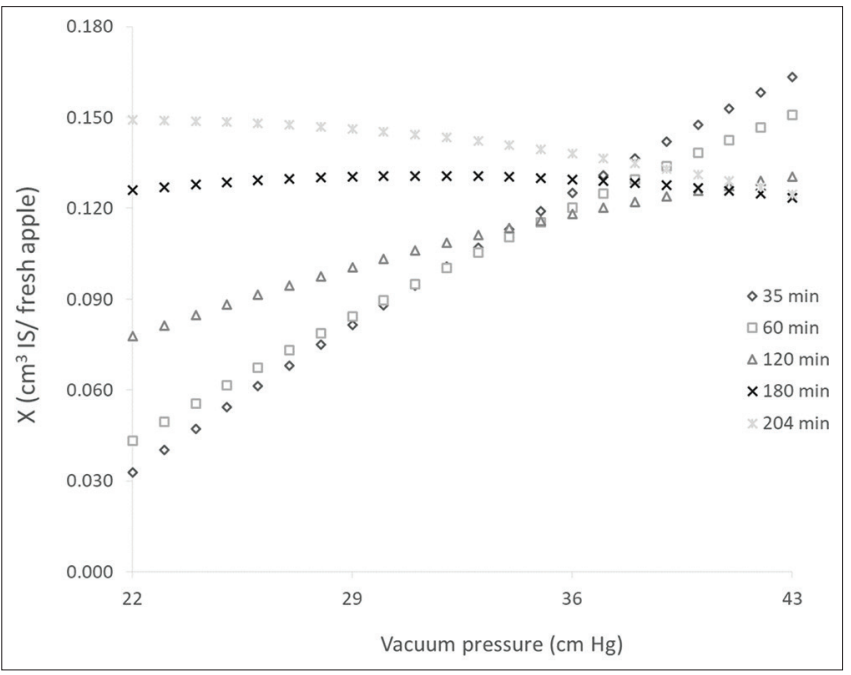

Fig 2. Volumetric impregnation parameter $(X)$ in apple tissue, as a function as vacuum pressures $(22-43 \mathrm{~cm} \mathrm{Hg})$ and relaxation time (35 - 204 min.).
This incorporation requires techniques such as vacuum impregnation, which allows the impregnation of an external liquid, through pressure gradients to incorporate functional components into fruit tissues (de Oliveira et al., 2017). Impregnation is a hydrodynamic mechanism, where the pore space is filled by a solution, and then the expansion of gas trapped within the pores occurs, leading to an increase in volume (Ashitha and Prince, 2018). IS transfer is a result of mechanically-induced differences in atmospheric pressure. Impregnation with IS occurs as a consequence of a hydrodynamic mechanism and deformation-relaxation phenomena, in which the intracellular capillaries are filled (Radziejewska-Kubzdela et al. 2014). Vacuum impregnation technique therefore allows IS to be impregnated more than three times into the product, as compared to other techniques (De Oliveira et al., 2017).

Fig. 3 shows concentration of B. coagulans impregnated into apple slices as a function of vacuum conditions. The range obtained in our study was of 2 to $4 \times 10^{7} \mathrm{CFU}$ per $\mathrm{g}$ of apple. Many authors consider the values of $10^{6}-10^{7} \mathrm{CFU} \mathrm{g}{ }^{-1}$ as the minimum microbial content to maintain probiotic function (Rascón et al., 2018), and found that commercial probiotic products contain similar concentrations (Betoret et al., 2012; De Oliveira et al., 2014; Madureira et al., 2011; Rößle et al., 2010; Shori, 2015).

Betoret et al. (2003), reported that vacuum impregnation in apples cv. Granny Smith can incorporate $10^{7} \mathrm{CFU} \mathrm{g}^{-1}$ of Lactobacillus casei after applying a vacuum pressure of 50 mbar for $10 \mathrm{~min}$., and then the samples were left $10 \mathrm{~min}$. more in the liquid.

Fig. 3 shows CFU of B. coagulans according to relaxation time and vacuum pressure. At any relaxation time the

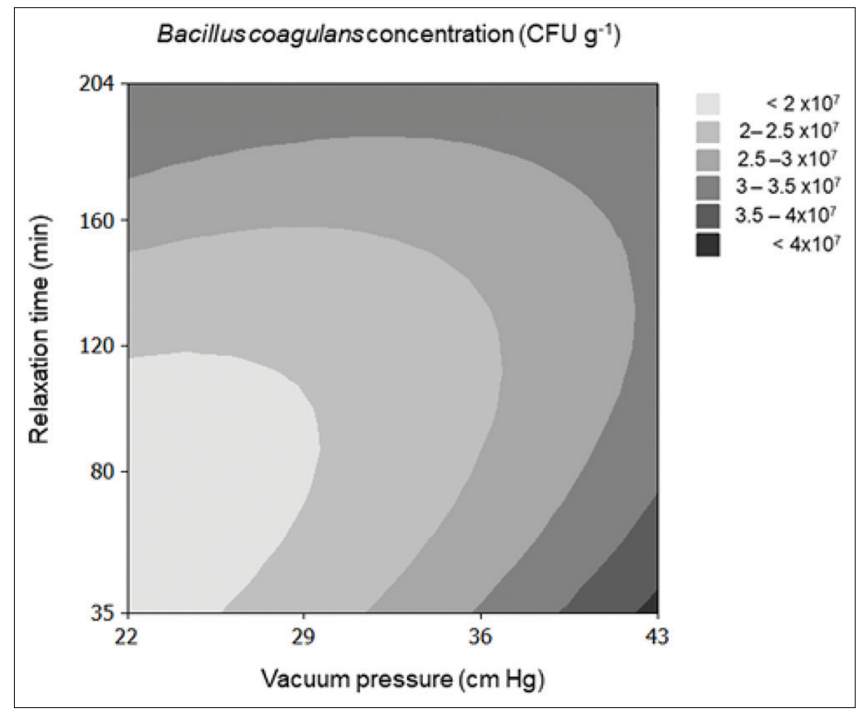

Fig 3. Impregnation of $B$. coagulans into apple slices at different vacuum pressures and relaxation time. 
higher the vacuum pressure, the higher the $B$. coagulans concentration obtained $\left(10^{7}\right)$. However, a slightly higher concentration $4 \times 10^{7}$ was observed in a short relaxation time (35 min.) and high vacuum pressure $(43 \mathrm{~cm} \mathrm{Hg})$. These conditions were similar to those where the highest $\mathrm{X}$ value was obtained.

Vacuum impregnation of bacteria into the porous structure of the apple allows its fortification. We observed that high vacuum pressure was sufficient to allow a great incorporation of Bacillus into the samples.

Similar to our vacuum pressure conditions Derossi et al. (2012) and Phianmongkhol and Wirjantoro (2016) suggest that a vacuum pressure up to $37 \mathrm{~cm} \mathrm{Hg}$ is required to incorporate a sucrose solution into apple fruit. However, we suggest that a vacuum pressure of around $40 \mathrm{~cm} \mathrm{Hg}$ can be used to impregnate $B$. coagulans at concentrations of $3.5-4 \times 10^{7} \mathrm{CFU} \mathrm{g}^{-1}$ of apple.

Through this vacuum impregnation methodology, it was possible to incorporate probiotic bacteria into the tissue structure. Air confined in the tissue flows out through the porous spaces of the fruit (Neri et al., 2016), in these spaces it was possible to incorporate the IS (Laurindo et al., 2007), thus impregnating the bacteria. This study presents good results for the incorporation of commercially applicable probiotics in apples.

According to the SEM images, apple slices did not show tissue changes because it has a typical surface of an apple subjected to vacuum pulses and lyophilization (Deng and Zhao, 2008). In addition, it was observed that B. coagulans were successfully impregnated on apple fruit surface with a Bacillus size around $3.9 \mu \mathrm{m}$.

\section{Factors that could affect bacterial viability}

Vacuum impregnation of B. coagulans in fruit requires certain physicochemical properties, for example, the appropriate viscosity of the solution should be used to allow flow within the pores and intercellular spaces (Betoret et al., 2012).

During flow of the bacterial solution into the tissue, viscosity forces can suppress flow rate due the impact of solution in contact with surface tissue and shear forces (Van Liedekerke et al., 2011). The bacteria to be impregnated are fixed to the solid (tissue) in a certain layer as occurred with B. coagulans (Fig. 4). A boundary layer is formed when a flow of the isotonic solution strikes a flat wall (Rastogi et al., 2014), in this case, apple tissue.

The higher the distance or tissue depth the higher the disturbance flow, therefore flow change from laminar to

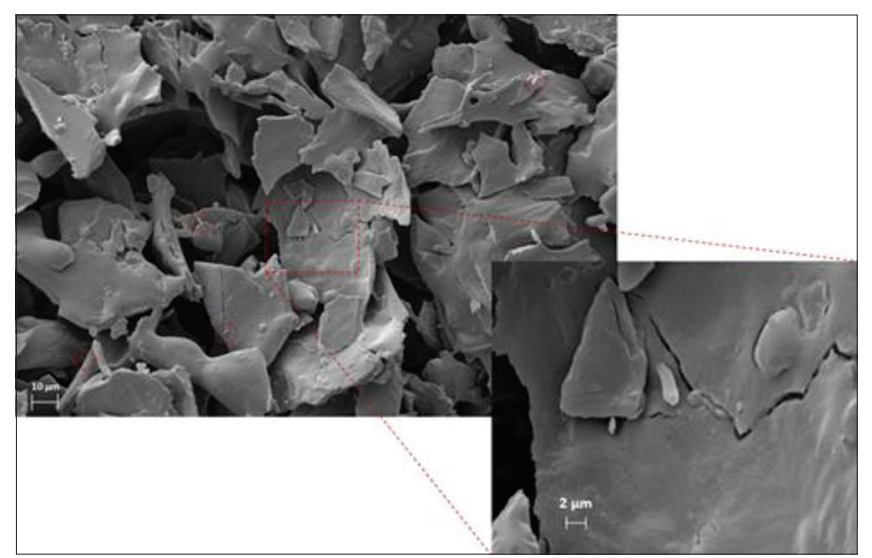

Fig 4. Scanning electron microscopy (SEM) micrograph of $B$. coagulans in apple tissue treated with osmotic treatment.

turbulent (Kähler et al., 2006). There is a possibility that these forces, speeds and shear effects cause the bacteria to collide with particles and tissue while it is being impregnated into the apple slice. During these collisions, some of the bacterial cells may become non-viable, which may be one of the reasons why their population decreases.

Othe reason that may explain this reduction may be the lack of oxygen during the $5 \mathrm{~min}$. of vacuum (Nótin et al., 2011). Due to their small size, prokaryotic cells undergo changes more directly than cells of multicellular organisms (Kroos, 2005).

Turgor pressure in the bacteria cytoplasm is relatively constant because the cytoplasmic membrane matches the stiffness of the cell wall. This turgor pressure allows the bacteria to withstand sudden changes in solute concentration in its environment, within certain limits (Szymanski and Cosgrove, 2009).

The concentration of solids absorbed and loss of water that bacteria face exposes them to high osmotic pressures. Bacteria must use their energy to maintain their turgor, instead of using it for other metabolic processes; therefore, cells lose viability (Jayaprakasha et al., 1997). Higher water migration and sugar gain in the surface of the fruit has been reported by Bchir et al. (2009) and Ganjloo et al. (2014).

To accurately determine bacterial cell viability, techniques such as cell viability through flow cytometry make it possible to count number of cells at several morbidity stages between living and dead cells, since the technique allows identifying membrane alterations and metabolic state of individual cells (Avila-Quezada and Espino-Solis, 2019).

A high cell viability ensures effectiveness of the probiotic bacteria (Champagne et al., 2018), and helps to discern which impregnation conditions are effective and less 
aggressive with the probiotic cell, after insertion into the tissue (Rodrigues et al., 2018).

For future studies we recommend the use of cell viability technique by flow cytometry to measure several levels of morbidity and determine why does the concentration change from $10^{10}$ to $10^{7}$, when probiotics are impregnated into fruit tissues. Future studies should also determine ideal conditions to incorporate probiotic microorganisms into diverse fruit samples, and even, try to impregnate biocontrol microorganisms in whole fruits to protect them from postharvest plant pathogens.

\section{CONCLUSIONS}

The conditions for a notably content of probiotics integrated into the apple matrix depend on several factors such as the impregnation vacuum pressure and time, the impregnation IS and relaxation time. The enrichment of apple slices was achieved with a sucrose IS of $14^{\circ} \mathrm{Bx}$ containing an initial concentration of $10^{10} \mathrm{CFU}$ g- 1 of $B$. coagulans.

The process of high vacuum pressure $(43 \mathrm{~cm} \mathrm{Hg}$ during $5 \mathrm{~min}$.) at any of the tested relaxation time $(35,60,120$, 180 and $204 \mathrm{~min}$.), produces a good final concentration $10^{7} \mathrm{CFU} \mathrm{g} \mathrm{g}^{-1}$ of the probiotic bacterium B. coagulans into fresh apple slices; a dose usually found in commercial probiotic products. Besides, all relaxation times, yielded similar volume fraction impregnation $(\mathrm{X})$ values between 11 and $14 \%$ at $39 \mathrm{~cm} \mathrm{Hg}$. Therefore, this study proposes apple slices as a suitable matrix to incorporate probiotic bacteria.

\section{ACKNOWLEDGEMENTS}

The authors thank to the National Council of Science and Technology of Mexico, through the National Postgraduate Horticulture Program of the Faculty of Agrotechnological Sciences of the Universidad Autonoma de Chihuahua.

\section{Authors' contributions}

Soto-Caballero M.C., Avila-Quezada G.D.: Funding acquisition; Conceptualization; Experiment design; Experiment performer; Drafted the manuscript; Data analysis. Acosta-Muñiz C.H., Chávez-Leal V.: Raw material resource; Conceptualization; Experiment design; Experiment performer. González-Aguilar G.: Research supervision; Drafted the manuscript. Soria-Hernández C.G.: Experiment performer; Manuscript review. All authors revised the document critically and approved the final manuscript for submission to the Journal.

\section{REFERENCES}

Abhari, K., S. S. Shekarforoush, S. Hosseinzadeh, S. Nazifi, J. Sajedianfard and M. H. Eskandari. 2016. The effects of orally administered Bacillus coagulans and inulin on prevention and progression of rheumatoid arthritis in rats. Food Nutr. Res. 60: 30876 .

Alzamora, S. M., D. Salvatori, M. S. Tapia, A. López-Malo, J. Welti-Chanes and P. Fito. 2005. Novel functional foods from vegetable matrices impregnated with biologically active compounds. J. Food Eng. 67: 205-214.

Ashitha, G. N. and M. V. Prince. 2018. Vacuum impregnation: Applications in food industry. Int. J. Food Ferment. Technol. 8: 141-151.

Assis, F. R., L. G. G. Rodrigues, G. Tribuzi, P. G. de Souza, B. A. M. Carciofi and J. B. Laurindo. 2019. Fortified apple (Malus spp. cv. Fuji) snacks by vacuum impregnation of calcium lactate and convective drying. LWT Food Sci. Technol. 113: 108298.

Avila-Quezada, G., E. Sánchez, A. A. Gardea-Béjar and E. AcedoFélix. 2010. Salmonella spp. and Escherichia coli: Survival and growth in plant tissue. N. Z. J. Crop Hortic. Sci. 38: 47-55.

Avila-Quezada, G. D. and Espino-Solis, G. P. 2019. Silver nanoparticles offer effective control of pathogenic bacteria in a wide range of food products. In: Pathogenic Bacteria. Interchopen, Croatia. Available from: https://www.intechopen.com/online-first/silvernanoparticles-offer-effective-control-of-pathogenic-bacteria-ina-wide-range-of-food-products. [Last accessed on 2020 Oct 02].

Bchir, B., S. Besbes, H. Attia and C. Blecker. 2009. Osmotic dehydration of pomegranate seeds: Mass transfer kinetics and differential scanning calorimetry characterization. Int. J. Food Sci. Technol. 44: 2208-2217.

Betoret, N., L. Puente, M. J. Dıaz, M. J. Pagan, M. J. Garcia, M. L. Gras, J. Martínez-Monzó and P. Fito. 2003. Development of probiotic-enriched dried fruits by vacuum impregnation. J. Food Eng. 56: 273-277.

Castagnini, J. M., N. Betoret, E. Betoret and P. Fito. 2015. Vacuum impregnation and air drying temperature effect on individual anthocyanins and antiradical capacity of blueberry juice included into an apple matrix. LWT Food Sci. Technol. 64: 1289-1296.

Champagne, C. P., A. G. da Cruz and M. Daga. 2018. Strategies to improve the functionality of probiotics in supplements and foods. Curr. Opin. Food Sci. 22: 160-166.

Cotter, P. D., R. P. Ross and C. Hill. 2013. Bacteriocins-a viable alternative to antibiotics? Nat. Rev. Microbiol. 11: 95-105.

De Oliveira, P. M., B. R. Leite Júnior, M. L. Martins, E. M. F. Martins and A. M. Ramos. 2014. Minimally processed yellow melon enriched with probiotic bacteria. Semin. Cienc. Agrar. 35: 2415-2426. Available from: https://www.locus.ufv.br/ handle/123456789/17845. [Last accessed on 2020 Oct 08].

de Oliveira, P. M., A. M. Ramos, E. M. F. Martins, E. N. R. Vieira, A. D. S. Soares and M. C. de Noronha. 2017. Comparison of vacuum impregnation and soaking techniques for addition of the probiotic Lactobacillus acidophilus to minimally processed melon. Int. J. Food Sci. Technol. 52: 2547-2554.

Derossi, A., T. de Pilli and C. Severini. 2012. The application of vacuum impregnation techniques in food industry. In: Valdez, B., (Ed.), Scientific, Health and Social Aspects of the Food Industry. In Tech Europe, Croatia, pp. 25-56.

Deng, Y. and Y. Zhao. 2008. Effect of pulsed vacuum and ultrasound osmopretreatments on glass transition temperature, texture, microstructure and calcium penetration of dried apples (Fuji). Food Sci. Technol. 41: 1575-1585. 
Elshaghabee, F. M., N. Rokana, R. D. Gulhane, C. Sharma and H. Panwar. 2017. Bacillus as potential probiotics: Status, concerns, and future perspectives. Front. Microbiol. 8: 1490.

Flores-Andrade, E., L. A. Pascual-Pineda, F. G. Alarcón-Elvira, M. P. Rascón-Díaz, D. J. Pimentel-González and C. I. Beristain. 2017. Effect of vacuum on the impregnation of Lactobacillus rhamnosus microcapsules in apple slices using double emulsion. J. Food Eng. 202: 18-24.

Ganjloo, A., R. A. Rahman, J. Bakar, A. Osman and M. Bimakr. 2014. Optimization of osmotic dehydration of seedless guava (Psidium guajava L.) in sucrose solution using response surface methodology. Int. J. Food Eng. 10: 307-316.

Granato, D., G. F. Branco, F. Nazzaro, A. G. Cruz and J. A. F. Faria. 2010. Functional foods and non dairy probiotic food development: Trends, concepts, and products. Compr. Rev. Food Sci. Food Saf. 9: 292-302.

Guan, Y., C. Peace, D. Rudell, S. Verma and K. Evans. 2015. QTLs detected for individual sugars and soluble solids content in apple. Mol. Breed. 35: 135.

Haldar, L. and D. N. Gandhi. 2016. Effect of oral administration of Bacillus coagulans B37 and Bacillus pumilus B9 strains on fecal coliforms, Lactobacillus and Bacillus spp. in rat animal model. Vet. World. 9: 766.

International Organization for Standardization. 1993. Method ISO No. 793. $2^{\text {nd }}$ ed. International Organization for Standardization, Geneva, Switzerland.

Jager, R., K. A. Shields, R. P. Lowery, E. O. de Souza, J. M. Partl, C. Hollmer, M. Purpura and J. M. Wilson. 2016. Probiotic Bacillus coagulans GBI-30, 6086 reduces exercise-induced muscle damage and increases recovery. PeerJ. 4: e2276.

Jayaprakasha, H. M., K. Jayaraj Rao and W. A. Lokesh Kumar. 1997. Studies on the influence of water activity (aw) on the stability of foods: A critical appraisal. J. Food Sci. Technol. (Mysore). 34: 273-285.

Joshi, A., A. Kar, S. G. Rudra, V. R. Sagar, E. Varghese, M. Lad, I. Khan and B. Singh. 2016. Vacuum impregnation: A promising way for mineral fortification in potato porous matrix (potato chips). J. Food Sci. Technol. 53: 4348-4353.

Jurenka, J. S. 2012. Bacillus coagulans: Monograph. Altern. Med. Rev. 17: 76-81.

Kähler, C. J., U. Scholz and J. Ortmanns. 2006. Wall-shear-stress and near-wall turbulence measurements up to single pixel resolution by means of long-distance micro-PIV. Exp. Fluids. 41: 327-341.

Kourkoutas, Y., M. Kanellaki and A. A. Koutinas. 2006. Apple pieces as immobilization support of various microorganisms. LWT Food Sci. Technol. 39: 980-986.

Kroos, L. 2005. Eukaryotic-like signaling and gene regulation in a prokaryote that undergoes multicellular development. PNAS. 102: 2681-2682.

Laurindo, J. B., G. B. Stringari, S. S. Paes and B. A. M. Carciofi. 2007. Experimental determination of the dynamics of vacuum impregnation of apples. J. Food Sci. 72: 470-475.

Lewicki, P. P. and R. Porzecka-Pawlak. 2005. Effect of osmotic dewatering on apple tissue structure. J. Food Eng. 66: 43-50.

Madureira, A. R., M. Amorim, A. M. Gomes, M. E. Pintado, and F. X. Malcata. 2011. Protective effect of whey cheese matrix on probiotic strains exposed to simulated gastrointestinal conditions. Food Res. Int. 44: 465-470.

Mendoza, F., P. Verboven, Q. T. Ho, G. Kerckhofs, M. Wevers and B. Nicolaï. 2010. Multifractal properties of pore-size distribution in apple tissue using X-ray imaging. J. Food Eng. 99: 206-215.

Mujica-Paz, H., A. Valdez-Fragoso, A. López-Malo, E. Palou and J.
Welti-Chanes. 2003. Impregnation properties of some fruits at vacuum pressure. J. Food Eng. 56: 307-314.

Neri, L., L. D. Biase, G. Sacchetti, C. di Mattia, V. Santarelli, D. Mastrocola and P. Pittia. 2016. Use of vacuum impregnation for the production of high quality freshlike apple products. J. Food Eng. 179: 98-108.

Nótin, B., M. Stéger-Máté, R. Juhász, D. Jakab, J. Monspart-Sényi and J. Barta. 2011. Changes of phenolic compounds in black currant during vacuum drying process. Acta Aliment. 40: 120-129.

Official Methods of Analysis. 2000. Method No. 980.31. 17 th ed. AOAC International, Gaithersburg, MD.

Peres, C. M., C. Peres, A. Hernández-Mendoza and F. X. Malcata. 2012. Review on fermented plant materials as carriers and sources of potentially probiotic lactic acid bacteria-with an emphasis on table olives. Trends Food Sci. Technol. 26: 31-42.

Phianmongkhol, A. and T. I. Wirjantoro. 2016. Effect of ripening stage and vacuum pressure on vacuum impregnated mango Chok Anan. Int. Food Res. J. 23: 1085-1091.

Radziejewska-Kubzdela, E., R. Biegańska-Marecik and M. Kidoń. 2014. Applicability of vacuum impregnation to modify physicochemical, sensory and nutritive characteristics of plant origin products-a review. Int. J. Mol. Sci. 15: 16577-16610.

Ranadheera, R. D. C., S. K. Baines and M. C. Adams. 2010. Importance of food in probiotic efficacy. Food Res. Int. 43: 1-7.

Rascón, M.P., K. Huerta-Vera, L.A. Pascual-Pineda,A.Contreras-Oliva, E. Flores-Andrade, M. Castillo-Morales, E. Bonilla and I. González-Morales. 2018. Osmotic dehydration assisted impregnation of Lactobacillus rhamnosus in banana and effect of water activity on the storage stability of probiotic in the freezedried product. LWT Food Sci. Technol. 92: 490-496.

Rastogi, N. K., K. S. M. Raghavarao and K. Niranjan. 2014. Recent developments in osmotic dehydration. In: Sun, D. W. (Ed.), Emerging Technologies for Food Processing Academic Press. University College Dublin, National University of Ireland, Dublin, Ireland, pp. 181-212.

Rößle, C., M. A. E. Auty, N. Brunton, R. T. Gormley and F. Butler. 2010. Evaluation of fresh-cut apple slices enriched with probiotic bacteria. Innov. Food Sci. Emerg. Technol. 11: 203-209.

Rodrigues, S., L. C. Silva, A. Mulet, J. A. Cárcel and F. A. Fernandes. 2018. Development of dried probiotic apple cubes incorporated with Lactobacillus casei NRRL B-442. J. Funct. Foods. 41: 48-54.

Russo, P., M. L. V. de Chiara, A. Vernile, M. L. Amodio, M. P. Arena, V. Capozzi, S. Massa and G. Spano. 2014. Fresh-cut pineapple as a new carrier of probiotic lactic acid bacteria. Biomed. Res. Int. 2014: 309183.

Schulze, B., S. Peth, E. M. Hubbermann and K. Schwar. 2012. The influence of vacuum impregnation on the fortification of apple parenchyma with quercetin derivatives in combination with pore structures X-ray analysis. J. Food Eng. 109: 380-387.

Shori, A. B. 2015. The potential applications of probiotics on dairy and non-dairy foods focusing on viability during storage. Biocatal. Agric. Biotechnol. 4: 423-431.

Sumi, C. D., B. W. Yang, I. C. Yeo, and Y. T. Hahm. 2014. Antimicrobial peptides of the genus Bacillus: A new era for antibiotics. Can. J. Microbiol. 61: 93-103.

Szymanski, D. B. and D. J. Cosgrove. 2009. Dynamic coordination of cytoskeletal and cell wall systems during plant cell morphogenesis. Curr. Biol. 19: R800-R811.

Tappi, S., U. Tylewicz, S. Romani, M. Dalla Rosa, F. Rizzi and P. Rocculi. 2017. Study on the quality and stability of minimally processed apples impregnated with green tea polyphenols 
during storage. Innov. Food Sci. Emerg. Technol. 39: 148-155.

Ugras, S., K. Sezen, H. Kati and Z. Demirbag. 2013. Purification and characterization of the bacteriocin Thuricin Bn1 produced by Bacillus thuringiensis subsp. kurstakiBn1 isolated from a hazelnut pest. J. Microbiol. Biotechnol. 23: 167-176.

Zunin, P., F. Turrini, R. Leardi and R. Boggia. 2017. Olive fruits and vacuum impregnation, an interesting combination for dietetic iron enrichment. J. Food Sci. Technol. 54: 481-487.

Puente, D. L., V. N. Betoret and R. M. Cortés. 2009. Evolution of probiotic content and color of apples impregnated with lactic acid bacteria. Vitae. 16: 297-303.

van Liedekerke, P., P. Ghysels, E. Tijskens, G. Samaey, D. Roose and H. Ramon. 2011. Mechanisms of soft cellular tissue bruising. A particle based simulation approach. Soft Matter. 7: 3580-3591. 